15. Минасян Р.С. Способы изготовления платежных слитков // Петербургский археологич.вестник. 1995. Вып.9. (Сб.памяти А.М. Микляева). С.168-172.

16. Комар А.В. Платежные слитки черниговского типа // Города и веси средневековой Руси: археология, история, культура: к 60-летию Н.А.Макарова. М..: - Вологда: Древности Севера, 220156, с.534-534.

17. Комар А.В. Цит.соч., фототабл.на с.536.

18. http: //rodnaya-vyatka.ru/places/105398. Дата обращения 28,09,2021.

19. Для археолога приведены данные вполне подходяще для реального обследования местности, что еще предстоит сделать. Правда, И.А. Талицкая приводит поистине навигационные координаты дер.Масленникова как 590 $40^{\prime}$ и 52³0'. См.: Талицкая И.А. Цит.соч., с.185 сл. Вместе с этими работами необходимо дальнейшее архивно-библиографическое изучение памятника денежного обращении Вятской земли, ввиду того, что Талицкая сообщает о неопознанной вещице из серебра весом 72 г. , а это, лишь на первый взгляд позволяет предположить о находках Масленникова со средним весом серебряных изделий равных 153 г., что недостаточно до киевской весовой нормы домонгольской поры. Да и изложенное в данной работе противоречит подобным намерениям.

20. Данный клад также не имеет прямых датирующих признаков, имя ввиду наличие гигантского китайского серебряного ямба-слитка усеченной формы и ювелирных изделий. Все - 12 в. Последний мог попасть на верхнюю Камы в Пермь Великую транзитом через Волжскую Булгарию из Центральной Азии. См.: Ивочкина Н.В. К истории эрмитажного собрания китайских слитков (ямбов) // Нумизматика в Эрмитаже. Л.: Б.и., 1987, с.71-82; Она же. Обращение Ямбового весового серебра в Китае и распространение его на территории Средней Азии и Казахстана в 12-18 вв. // Средневековая городская культура Казахстана и Средней Азии. Алма-Ата, 1983, с.93-102; Талицкая И.А. Цит.соч.

21. Валеев Р.М. Цит.соч. , с.88, 142. № 18; с.155, с.30, 31.

\title{
Худобородов А.Л., Самохина А.В. \\ Советское государство в критические периоды своей истории: некоторые дискуссионные и спорные вопросы
}

ФГБОУ ВО «Южно-Уральский государственный гуманитарно-педагогический университет»

(Россия, Челябинск)

doi: $10.18411 / s r-05-12-2021-42$

\section{Аннотация}

В данной статье дан анализ развития СССР в очень сложные, критические периоды - Великая Отечественная война и распад СССР. Несмотря на наличие разных точек зрения на происходящие события, в частности сотрудничество с фашистами против советского политического режима, причины разрушения СССР есть то, что их объединяет - не безразличное отношение к Советскому союзу.

Ключевые слова: СССР, советский политический режим, Великая Отечественная война, распад СССР.

\section{Abstract}

This article analyzes the development of the USSR in very difficult, critical periods the Great Patriotic War and the collapse of the USSR. Despite the existence of different points of view on current events, in particular cooperation with the Nazis against the Soviet political regime, the reasons for the destruction of the USSR are what unites them - not indifferent attitude towards the Soviet Union.

Keywords: USSR, Soviet political regime, Great Patriotic War, collapse of the USSR.

В истории советского государства было немало переломных и драматических периодов: гражданская война 1918-1920 гг.; социалистический эксперимент, выразившийся в коллективизации, культурной революции, индустриализации; Великая Отечественная война, и др. Среди них были и критические периоды, когда решалась судьба Советского союза, была угроза его гибели. Это, например, периоды Великой Отечественной войны и распада СССР в 1990-1991 гг. 
В эти годы особо яростным нападкам со стороны врагов советского строя подвергался советский политический режим, его якобы антинародный характер, и именно борьбой против этого режима оправдывалось, например, сотрудничество с фашистами, подрывная деятельность против советской страны и его народа. По этим проблемам в нашем обществе и исторической науке до сих пор идут дискуссии и споры, возрождается мифологизированное сознание [1;2].

Известно, что большинство российских эмигрантов, несмотря на враждебное отношение к сталинскому политическому режиму, были оборонцами в 1941-1945 гг., выступали в защиту СССР от гитлеровской агрессии, стояли на патриотических позициях. В то же время часть белой эмиграции выступала за поражение СССР в войне с Германией, такие эмигранты стояли на пораженческих позициях. Возникает вопрос: почему?

В этом отношении характерна жизнь и политическая деятельность в 1930-е - 1945 гг. писателя, бывшего атамана Донского казачьего войска Н.Н. Краснова. В последние десятилетия всё еще наблюдается героизация участия П.Н. Краснова и других казаковэмигрантов в борьбе против советского народа в составе вермахта.

Так, Георгий Кокунько заявил в 2002 г. в предисловии к воспоминаниям П.Н. Краснова «Незабываемое 1945-1956»: «Не против России они воевали - их врагом был ненавистный советский режим, уничтоживший области казачьих войск и казачьи вольности, режим, который уничтожил и обрек на вымирание от голода миллионы россиян. И вынужденным сотрудничеством с Германией в 1941 году для многих в СССР лишь возобновилась Гражданская война» [3].

Другие авторы изображают П.Н. Краснова наивным политическим деятелем, который излишне доверился руководителям «Третьего рейха» и был ими жестоко обманут. Тверской исследователь В.А. Юдин в связи с этим утверждает: «Что сказать о сотрудничестве П. Краснова с гитлеровцами и трагической гибели генерала? Это черная страница его скорбной биографии. Борясь в эмиграции за автономию Дона, Краснов совершает роковой шаг: наивно поверив, что фашисты отдадут ему «независимый», «освобожденный» от коммунистов Дон, он просчитался» [4]. Подобной точки зрения придерживается и автор книги о П.Н. Краснове А.А. Смирнов [5].

Думается, это односторонний, во многом политизированный подход к оценке П.Н. Краснова, который прямо или косвенно направлен на оправдание политической ориентации П.Н. Краснова в 1939-1945 гг.

Прагматизм П.Н. Краснова, его беспринципность в сотрудничестве с гитлеровцами, довольно быстрый и резкий переход от сторонника «единой и неделимой России» к казачьему сепаратизму и покровителю самостийников в 1943 г. вызвали непонимание и неодобрение многих белых эмигрантов, в том числе генерала А.А. фон Лампе. Начальник «Объединения русских воинских союзов в Германии» А.А. фон Лампе писал 9 октября 1943 г. начальнику Юго-Восточного отдела объединения князю Гегелашвили: «Меня очень пугает «выход казачьих войск широким фронтом на авансцену борьбы». Пока что этот выход в лице генерала Краснова неудачен, так как знаменует собою (и в его лице, как это ни печально) возрождение недоброй памяти казачьего сепаратизма. Не того гнусного, что проповедуют самостийники в Праге, но достаточно неприятного и теперь. Так, генерал Краснов сам сказал мне, что «немцы восстановят (?) казачьи республики», и что «для приехавших с Дона понятия «большевик» и «русский» - синонимы», точно у казаков большевиков не было! Рядовое казачество давно уверяет немцев, что большевики - это только русские, но как, то же самое может делать Краснов?» [4].

А.А. Смирнов в своей книге «Атаман Краснов» утверждает, что «вплоть до июня 1943 года писатель, донской генерал и атаман Краснов с нацистами практически не сотрудничал» [5]. С этим трудно согласиться. Выявленные нами и опубликованные в 
журнале «Исторический архив» документы, в частности, переписка П.Н. Краснова с лидерами казачьей эмиграции явно свидетельствуют, что П.Н. Краснов был прекрасно осведомлён о всех аспектах политики германских властей в отношении российской эмиграции и настойчиво пропагандировал её среди казаков-эмигрантов. Об этом, например, прямо говорится в письме П.Н. Краснова атаману Общеказачьего объединения в Германской империи Е.И. Балабину в июле 1941 г. [6].

Более объективно и всесторонне анализируют эволюцию политической ориентации П.Н. Краснова в 1930-е - 1940-е гг. современные отечественные историки С.В. Карпенко, С.И. Дробязко, Ю.С. Цурганов.

Анализ приведенных выше материалов показывает, что не о судьбе российского и казачьего народа, не о борьбе со сталинизмом и советским политическим режимом заботились прежде всего П.Н. Краснов и другие пораженцы среди эмигрантов, а на первом месте было их тщеславные и политические амбиции, желание сохранить видные позиции в обозе гитлеровского режима.

В этом году исполняется 30 лет со дня разрушения СССР. В российском обществе, в исторической и политической науке до сих пор не ослабевают ожесточенные споры и дискуссии о причинах этого события, о крахе Советской политической системы. При анализе причин распада СССР можно выделить три подхода к этой проблеме.

Первая точка зрения характерна для либеральных историков и политологов, она была господствующей в официальной российской пропаганде в 1990-х гг. Согласно этой версии, Советский Союз с самого начала был «империей зла» (по терминологии Р. Рейгана) [7]. На протяжении всей советской истории в стране царил тоталитарный политический режим, террор и подавление всяких свобод личности. Советский период это «чёрная дыра» в отечественной истории, ничего положительного этот политический режим народу и обществу не дал, и как всякая империя советское государство неизбежно должно было развалиться никакой, другой альтернативы не было. Подобной точки зрения в наши дни придерживаются правящие круги бывших советских республик в Средней Азии, а также Казахстана. По мнению лидеров этих республик, советское государство принесло населению этих регионов одни ужасы, страдания, подавление национальных традиций и культуры. С таким подходом к оценке СССР согласиться категорически нельзя.

Согласно второй точке зрения СССР всегда был могучим государством, оплотом мира и социального прогресса на планете, никаких объективных предпосылок для его распада не было к началу 1990-х гг. И если Советский Союз всё же распался, то только в результате подрывной деятельности мирового империализма и предательства «агентов влияния» Запада в лице М.С. Горбачева, Б.Н. Ельцина, Э.А. Шеварднадзе, А.Н. Яковлева и других инициаторов перестройки. Такой позиции придерживается лидеры коммунистов современной России. На наш взгляд, такая позиция несколько наивна и примитивна. Если следовать логике этой версии, то СССР был по существу «Колосс на глиняных ногах», никаких серьёзных внутренних противоречий в его развитии не было и для его развала достаточно было внешнего фактора и предательства внутри советской политической элиты.

Но есть и третья точка зрения, которой придерживаются и авторы этой статьи [8]. На наш взгляд, Советский Союз был здоровым политическим и экономическим организмом, на протяжении всей своей истории обладал серьёзным потенциалом для своего развития. Но надо признать, что для СССР были характерны и некоторые глубокие внутренние противоречия и трудности, которые до конца так и не были преодолены. Например, тоталитарный политический режим в сталинскую эпоху, авторитарный режим в период правления Н.С. Хрущева и Л.И. Брежнева, административно-командная система управления экономикой ее позволили обеспечить сбалансированное развитие экономики Союза ССР в целом и экономики союзных республик. В экономическом развитии отдельных республик были допущены крупные 
просчеты с точки зрения экологии и рационального природопользования, в частности, в ходе освоения целинных и залежных земель в Казахстане в 1950-х гг., интенсивного развития хлопководства в Узбекистане в 1970-х - 1980-х гг. и гибели Аральского моря. В дальнейшем национальные политические элиты этих и других союзных республик обвинили исключительно Союзный центр, Кремль в этих и подобных экономических просчетах и ошибках.

Нужно учесть, что федеративное устройство РСФСР и СССР не было последовательно проведено, самостоятельность союзных республик ее всегда обеспечивалась, области и края не были субъектами РСФСР.

Конечно, все эти проблемы и ошибки вполне можно было разрешить, но трагедия СССР состояла в том, что в стране не оказалось такого гениального политического лидера, как Дэн Сяопин в Китае. И во второй половине 1980-х гг., в период «перестройки» в распаде СССР исключительную роль играл субъективный политический фактор, неспособность лидеров советской державы мобилизовать здоровые силы народа для противодействия развалу СССР. По нашему мнению, фатальной неизбежности гибели СССР не было, но в конце 1980-х - начале 1990-х гг. свою роковую, негативную роль сыграл субъективный фактор.

Конечно, возродить СССР в прежнем виде уже невозможно. Но для сохранения единства и целостности современной Российской Федерации нужно учесть уроки прошлого.

$$
* * *
$$

1. Рыбаков, В.А. Советское государство: эволюция политического режима // Вестник Омского университета. Серия «Право». 2016. № 3(48). С. 32-38.

2. Сперанский, А.В. Советская модель управления: теоретические дискуссии и политическая практика // Отечественная история. 2019. №4. С. 46-52.

3. Краснов, П.Н. Незабываемое, 1945-1956 / П.Н. Краснов. - Сан Франциско: Рус. жизнь, Сор. 1957. $351 \mathrm{c}$.

4. Россия в войнах XX века: материалы Всероссийской научно-практической конференции / Отв. ред. В.Н. Ратушняк. - Краснодар: Кубанькино, 2003. - 270 с.

5. Смирнов, А.А. Атаман Краснов / А.А. Смирнов. - М.: АСТ; СПб.: Terra Fantastica, 2003. - 365.

6. «Мы щепки, забитые в заводь, подле бурно несущегося потока...» Русская эмиграция в Третьем рейхе. 1941-1943 гг. (Публикация документов с комментариями и примечаниями. Публикацию подготовил А.Л. Худобородов) // Исторический архив. 1998. № 3. С. 153-163.

7. Речь Рейгана 8 марта 1983 г. («Империя зла») [Электронный ресурс] / Р. Рейган. - текст. Режим доступа: http://www.coldwar.ru/raegan/evil_empire.php

8. Самохина, А.В. История России: учебное пособие / А.В. Самохина. - Челябинск: Изд-во ЮжноУрал. гос. гуманит.-пед. ун-та, 2021. - 214 с. 